\title{
FACES DA VIOLÊNCIA EM DE FLORES ARTIFICIAIS, DE JUSSARA SANTOS
}

\author{
Luiz Henrique Silva de Oliveira \\ Mestre em Teoria da Literatura / UFMG
}

\begin{abstract}
RESUMO
O objetivo deste trabalho é mapear as diversas cenas de violência contidas em De flores artificiais (2002), livro de contos infanto-juvenis escritos por Jussara Santos. Não menos importante, demonstrar os principais procedimentos aos quais recorre a autora para denunciar, através do texto literário, a incidência de atos violentos, de diversas ordens, sobre crianças, jovens, mulheres e não brancos.
\end{abstract}

\section{PALAVRAS-CHAVE}

Violência; Jussara Santos; literatura infanto-juvenil

Um dos temas mais controversos na literatura voltada para crianças e jovens é a violência. De um lado, estão autores e teóricos que se posicionam de maneira radicalmente contrária à exploração do tema, alegando estimular atitudes agressivas nos leitores. De outro, há os que defendem a tematização da violência como uma dentre diversas possibilidades de abordagem própria à literatura. Porém, raros são os que se preocupam em pensar que a violência em literatura nada mais representa do que as tensões sociais decantadas em palavras e traduzidas em pontos de vista enunciativos. Enquanto conteúdo social sedimentado, a escrita revela $e$ oculta os dilemas do passado e do presente.

Regina Dalcastagnè ${ }^{1}$ e Adécio de Souza Cruz $^{2}$ são seguros ao afirmar que na literatura brasileira canônica o ponto de vista da narração continua quase inalterado, partindo de um homem branco, escolarizado (ensino superior) e pertencente à classe média. À antípoda, encontra-se o alvo, sob os mais diversos tipos de mira: a "vítima preferencial”, a qual

\footnotetext{
${ }^{1}$ DALCASTAGNE. Estudos de literatura brasileira contemporânea: a personagem do romance.

${ }^{2}$ CRUZ. Narrativas contemporâneas da violência: Fernando Bonassi, Paulo Lins e Ferréz.
} 
pertencente a um grupo bastante distinto - jovens, mulheres, crianças e idosos, não brancos, que na sua maioria são muito pobres. No bojo da passividade social, típica da sociedade da imagem, emerge a “aceitação” da violência incidida em crianças, mulheres, negros, pobres ou favelados. Os pesquisadores ainda denunciam a cor das vítimas da violência, numa equação em que quanto mais melanina o sujeito possuir, mais alvo de violência ele se poderá se tornar. Em outras palavras: reitera-se aqui que estes sujeitos são as "vítimas preferenciais" da violência, ${ }^{3}$ em suas mais vastas e diversas formas de aparição, como assevera Dalcastagnè. ${ }^{4}$

Peter Hunt tem razão quando assinala que tem ocorrido na literatura infanto-juvenil em geral um movimento perverso de commoditização, o qual nivela por baixo e homogeneíza as narrativas. Isso porque, segundo o autor, a literatura para crianças e jovens, rentável negócio para os grandes conglomerados editoriais, tende a repetir esquemas narrativos já “consagrados” e, portanto, pouco oferecem o tão desejável “deslocamento”. ${ }^{5}$ Nesse sentido, também no caso do Brasil, os scripts predominantes são “mais do mesmo”, 6 o que resulta na repetição do tratamento dado à violência em esquemas narrativos, cujas vítimas preferenciais da violência permanecem inalteradas.

Em posição oposta a esse cenário, Jussara Santos parece refutar os lugares-comuns de uma literatura infanto-juvenil de origens em Monteiro Lobato (Reinações de Narizinho) até chegar em Walcyr Carrasco (Irmão negro), obras em que o problema da violência recai exatamente sobre as vítimas preferenciais, naturalizando o ato agressivo e deslocando o viés de análise para o lugar-comum da sobreposição dos mais fortes sobre os mais fracos. Como não poderia deixar de ser, na literatura de Jussara Santos, a linguagem denuncia o sofrimento das personagens, refutando a naturalização da violência incidente em alvos preestabelecidos. Não tenho o menor temor em afirmar que isso se deve à "escrevivência” instaurada na obra da autora, isto é, “a escrita de um corpo, de uma condição, de uma experiência negra no Brasil”,

\footnotetext{
${ }^{3}$ Segundo Yves Michaud, a origem latina da palavra violentia significa o uso deliberado da força, sobretudo física, do vigor, potência, aplicados em quantidade a alguém ou algo. O crítico ainda assinala que a violentia se liga à força em ação, o uso desmedido do recurso de força. Consequentemente, ensina Michaud, estas acepções deságuam em um inequívoco caráter violento daquele que agride não estando em legítima defesa. (Cf. MICHAUD. A violência.)

${ }^{4}$ DALCASTAGNE. Estudos de literatura brasileira contemporânea: a personagem do romance.

${ }^{5}$ HUNT. A infância sem clichês, p. 11.

${ }^{6}$ HUNT. A infância sem clichês, p. 12.
} 
que faz com que escrever possa muitas vezes deixar fluir o recalcado, o silenciado da História. ${ }^{7}$

Fernanda Rodrigues de Figueiredo ${ }^{8}$ destaca o olhar agudo da escritora sobre a realidade da minoria periférica, o qual enreda o leitor numa narrativa de cores fortes, em que se misturam o ambiente citadino, o barulho dos carros, buzinas, moradores de rua, músicas e a violência no asfalto e nos morros, bem como o cheiro erótico de pêssego e a procura inebriante pela escrita. As reflexões da autora ultrapassam o momento de leitura de seus livros, pois seus personagens e cenas, tão próximos do real, prolongam-se no imaginário do leitor. Aqueles vão de pessoas simples, como D. Ercília, a indivíduos mais complexos, a exemplo da narradora do conto "Das duas palavras ditas ao coronel”.

A violenta tensão entre os universos adulto e infantil se faz presente em diversos momentos do livro. Bom exemplo é “A vez da caça”. Mário, protagonista, é um escritor solitário e fracassado. Como muitos, vê no anonimato da internet a possibilidade de conversar com várias pessoas sem ser visto. "Enquanto conversava pela net, inventava personagens, criava situações, podia até se apaixonar.”’ Mário certa vez idealizara a possibilidade de o computador substituí-lo em diversas ocasiões, sobretudo as consideradas por ele como “chatas”, dentre elas, formaturas, velórios e casamentos. O personagem vive sob o signo do tédio. Para curar esse "mal” que lhe aflige, procurou se envolver com uma atividade bastante inusitada: "lançar-se na madrugada em companhia de Glória, sua colega de faculdade a caçar criancinhas. O segredo era descobri-las, caçá-las e não matá-las. Quando isso, por vezes

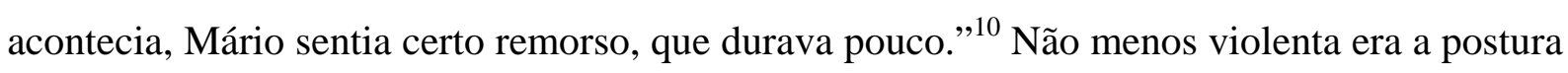
de Glória, companheira de caça de Mário. O nome da amiga pode ser lido como metáfora do que buscavam as personagens ao saírem para caçar: a "glória” para a existência repleta de tédio, através do abuso do mais forte contra o mais fraco. Ao fim e ao cabo, no país do massacre na Candelária, dos altos índices de violência infantil, contra a mulher e, mais recentemente, da invasão de atiradores a escolas, o conto discute, metaforicamente, a violência gratuita contra o outro. Se não, recordemos a postura de Glória: “Glória não estava

\footnotetext{
${ }^{7}$ EVARISTO. Da grafia-desenho de minha mãe, um dos lugares de nascimento de minha escrita, p. 20.

${ }^{8}$ FIGUEIREDO. Representação de minorias: a "reversão” do centro.

${ }^{9}$ SANTOS. De flores artificiais, p. 19.

${ }^{10}$ SANTOS. De flores artificiais, p. 20.
} 
nem aí ao prazer que sentia, ao gozo e êxtase ao qual era levada todas as vezes que saíam para caçar e, às vezes, matar.”11

Na calada da noite, Mário e Glória saem para a “diversão”. Carro posicionado estrategicamente para a fuga; armas a tiracolo; última olhadela para conferir a munição. Eis o que fazem os “caçadores” antes de encontrarem as crianças. Eles identificam os lugares onde se escondem suas presas pelos "pedaços de papelão e jornal, o cheiro de urina e fezes, os cobertores Paraíba, a cola. Lá estavam as crianças a dormir.”12 Os dois, como num game, chegam atirando para cima, riem enlouquecidos, fazendo com que meninos e meninas saíssem a correr pelas avenidas, até que seus pés, descalços, sangrem. Súbito, Mário encurrala um deles, que o olha firmemente. Glória replica: “- Audácia daquele menino.”13 Eis que foram mapeadas as vítimas preferenciais da violência. A cena somente pode fazer alusão às caçadas de safáris, acrescida de um agravante: o prazer hedonista de ver a caça humana em fuga e subserviência ao sadismo dos caçadores.

Inclusive, vale destacar que Mário busca na ficção - atividade que ele não realiza bem - inspiração para sua caçada. Recentemente, ele lera um conto chamado "O dia da caça" e ficara bastante contente em ver a sua atividade retratada ali. Nesse conto, um dos moleques, bastante ferido e com o corpo encolhido no chão, pede clemência, a fim de não ser morto. Seu algoz dispara duas vezes. De maneira a confundir realidade e ficção, Mário procura aplicar o que ele conhecera na teoria. Arrisco dizer que a o personagem, marcado pela bipolaridade, só se realiza vivendo a realidade através do prisma da ficção.

No entanto, certa vez, Mário e Glória saíram para caçar. Como em todas as vezes, chegaram à rua atirando para o alto, de modo que os meninos-caça, moradores de rua, pudessem correr. Um dos meninos ficou estático diante deles. O garoto nada dizia e mantinha os olhos fixos nos caçadores. “Atirar em caça parada não era do feitio daquele experiente caçador”, por isso, junto com Glória, começou a atirar próximo aos pés do menino, tentando fazer com que ele saísse do lugar, "mas o garoto mantinha-se quieto. Nada abalava aquela fortaleza em que ele parecia ter se convertido.”14 O garoto não corre e espera a aproximação dos dois. O coração deles bate com força, afinal, nunca haviam sido enfrentados numa caçada. O pequeno parecia-lhes uma fortaleza no olhar firme. Talvez possamos pensar, com Stuart

\footnotetext{
${ }^{11}$ SANTOS. De flores artificiais, p. 20.

${ }^{12}$ SANTOS. De flores artificiais, p. 20.

${ }^{13}$ SANTOS. De flores artificiais, p. 22.

${ }^{14}$ SANTOS. De flores artificiais, p. 22.
} 
Hall, que o corpo representa uma tela em que se inscrevem inúmeras marcas da dominação, da rebeldia e da resistência. "Existem aqui questões profundas de transmissão e herança cultural, de relações complexas entre as origens africanas e as dispersões irreversíveis da diáspora.” ${ }^{15}$ Uma dessas marcas parece ser o enfrentamento pelo olhar do menino, o que faz com que Mário entre em estado de choque e, posteriormente, delírio. Já de acordo com Muniz Sodré, o posicionamento determinado do corpo, variando de situação para situação, representa, em primeiro lugar, uma forma de orientação com referência aos outros; em segundo lugar, o corpo, nas tradições africanas, desempenha, não raro, papel fundamental na transmissão de conhecimentos. O saber veiculado pelo corpo

tem tanto a ver com a repetição ritmada de uma memória mítica fundamental para o grupo (...) quanto com ensinamentos presentes relativos, por exemplo, à posição do corpo em face de momentos cruciais como os de proteção à saúde, terapia, júbilo, cultuação, guerra. ${ }^{16}$

Em estado de alerta, o menino se posiciona, faz com que Mário e Glória recuem. Na ótica de Mário, atrás do corpo do garoto desdobram-se várias outras criancinhas, como que a cobrar pelos infortúnios causados. Metaforicamente, podemos pensar numa nova “onda negra”, agora em plena contemporaneidade, o que aponta para a não resolução dos problemas causados pelo legado escravista no Brasil.

O conto é finalizado com a cena de Mário e Glória indo embora, extremamente amedrontados, passando por meio ao grupo de crianças. Mário, posteriormente, já em sua residência, tenta conviver com o próprio fantasma que lhe assombrara a última noite de caçada.

A Mário, que tentava alcançar agora o silêncio do menino que lhe invadira o corpo, alma, espírito e coração, restava render-se ao ciúme e aos carinhos pegajosos de seu gato. Rubem amanheceria feliz. ${ }^{17}$

O conto, por fim, discute a omissão da população em relação à violência voltada contra os menos favorecidos, o que assinala uma característica marcante da literatura produzida por afrodescendentes. Objetiva-se marcar posições para além do campo artístico, atuar na construção psicológica e cultural do receptor, bem como fazê-lo refletir sobre a dinâmica de nossa sociedade:

\footnotetext{
${ }^{15}$ HALL. Da diáspora: identidades e mediações culturais, p. 343.

${ }^{16}$ SODRÉ. Samba, o dono do corpo, p. 125.

${ }^{17}$ SANTOS. De flores artificiais, p. 25.
} 
A população desconhecia os nomes dos caçadores, mas sabia que alguém, vez por outra se aventurava pela madrugada a caçar crianças. Porém, fazia ouvidos moucos. Fingia nada ver, nada saber. Portanto, quando a população ouvia o som do apito, os bares vinte e quatro horas eram fechados, as patrulhas sumiam das ruas, os carros e ônibus paravam de circular simultaneamente. A rua, de madrugada, era apenas da caça e dos caçadores. ${ }^{18}$

Dessa forma, o conto “A vez da caça” aborda a relação violenta contra uma das vítimas preferenciais: a criança. Aliás, esta toma da palavra e narra suas visões sobre a realidade, ainda que se valendo de devaneios. É o que acontece no conto "Da barriga do abutre”.

Talvez pudéssemos iniciar assim: era uma vez uma narradora-personagem, sem nome nem qualquer outra designação, que compartilhava com sua avó alguns delírios. A identificação entre neta e avó era tamanha, que até mesmo os delírios às vezes coincidiam. Certa vez, a avó acordou a casa inteira gritando que havia muitos gatos invadindo o quarto. Com exceção da pequena, todos nada viram. A criança, porém, não só os viu, como também de pronto se colocou a espantá-los. Quando as visões da avó eram boas, logo comentava com a neta; quando ruins, guardava todas elas para si e ficava amuada num canto.

Tempos depois, a pequena tem a mais impactante de suas visões: "uma das últimas que tive revelou-me um abutre, a barriga aberta de um abutre e por mais que tentasse, dele não consegui deduzir o azul.”19 $\mathrm{O}$ abutre caminhava com as vísceras abertas e para cada víscera parecia corresponder a uma narrativa da violência.

Aqui, o abutre funciona como metáfora de situações de morte. Toda a simbologia inerente ao abutre corrobora nossa hipótese. Os abutres são aves de rapina que se alimentam quase exclusivamente da carne dos animais mortos. A sua constante presença nos locais de morte tornou-os símbolos desta aos olhos dos Homens.

A exploração dos cadáveres com o consumo da carne apodrecida por parte dos abutres faz com que os humanos as sintam como verdadeiros símbolos da morte. Desde a Antiguidade esse fato tornou as relações do Homem com os abutres pouco amistosas, tendo sido estas aves alvos de perseguição humana ao longo dos tempos. Os locais mais frequentes de interação do Homem com os abutres eram os campos de batalha, onde chegava a haver grupos de soldados para afastar os abutres, de forma a impedir danos aos feridos.

\footnotetext{
${ }^{18}$ SANTOS. De flores artificiais, p. 21.

${ }^{19}$ SANTOS. De flores artificiais, p. 48.
} 
A presença do abutre no conto é elemento de identificação e/ou confirmação de morte iminente. Não somente a morte propriamente dita, mas o que poderíamos chamar de "morte social do sujeito”, ou seja, a existência em constante estado degradante e espoliação. E as três vísceras que a menina logo vê trazem três cenas de violência e morte que faziam parte do cotidiano dela - e da realidade brasileira.

Da primeira víscera: a narradora focaliza a história de Lia, uma garotinha de 8 anos a qual entrega roupas que sua mãe lavava. Na verdade, Lia não gostava mesmo era de Dona Rosa, “que sempre punha preço no serviço bem feito de sua mãe”. ${ }^{20}$ É implícito no conto a atribuição de valor que Dona Rosa ao serviço da mãe, o que, por sua vez, se desdobra na perspectiva de divisão social do trabalho da sociedade de classes. O trabalho manual, portanto, recebe pouco valor, ainda que bem feito.

Lia, contudo, parece viver à margem dos acontecimentos sociais, mesmo lugar que ocupa toda a sua família. A mãe, lavadeira; o tio, serviçal no clube da cidade em que moravam. A violência vinha a reboque da exclusão étnica. Um dos desejos de Lia era exatamente conhecer o clube. Entretanto, logo na entrada havia uma placa: “expressamente proibida a entrada de pessoas de cor naquele REIcinto.”21 Na minha leitura, o abutre anuncia esta cena, como denúncia de uma sociedade que está destruindo a si mesma com suas ações racistas. Não menos importante, podemos pensar a exclusão como ato de violência contra o menos favorecido economicamente e àquele de pele escura. A sociedade, assim, agride e lhe determina o que chamei há pouco de morte social, além de deixar bem explícita a vítima preferencial da violência.

Da segunda víscera: cena que trata da violência gratuita em relação ao outro. Dois jovens brincavam de roleta russa no mirante da cidade. "De lá sempre podiam mirar a cidade e acertar direto no alvo. (...) A cada ausência de uma bala, eles riam. (..) Na miragem, ouve-se apenas o estampido.”22 $\mathrm{O}$ conto mostra a banalização da violência e a sua gratuita incidência em relação ao outro.

Da terceira víscera: focaliza-se Zé, ou laranja, bucha de canhão, aviãozinho. Esses eram os apelidos da personagem que "fazia todo tipo de favor para qualquer que lhe pedisse”. ${ }^{23}$ Em formato de nota jornalística, o texto aponta o desfecho trágico e violento de

\footnotetext{
${ }^{20}$ SANTOS. De flores artificiais, p. 48.

${ }^{21}$ SANTOS. De flores artificiais, p. 49.

${ }^{22}$ SANTOS. De flores artificiais, p. 49.

${ }^{23}$ SANTOS. De flores artificiais, p. 49.
} 
Zé. Em dia de entrega mal feita, o resultado estava ali. "Laranja, bucha de canhão aviãozinho cravado de balas, com as vísceras sujas de areia misturando-se com as vísceras expostas do abutre.”24 Agonizando, Zé ainda pede à sua avó, que o acompanhava em seus últimos instantes, para contar-lhe uma história. A narrativa denuncia, pois, o rigor das leis do submundo do crime organizado e que também escolhe suas vítimas preferenciais.

Finalmente, em “Sem “Título II”, há a violência em relação ao sujeito não letrado, provavelmente oriundo das camadas menos favorecidas. Estar num mundo regido pela letra, em que a cultura letrada é permissão de acesso aos postos de valor na sociedade de classes não é tarefa fácil para quem não preenche estes requisitos. Por vezes, uma situação simples pode significar a construção do que chamo de "cidadania de segunda classe”, ou seja, uma cidadania em que falta o domínio da letra e, por isso, não pode ser plena. Nessa cidadania de segunda classe, o olhar do sujeito letrado condena a piori o não letrado ou o pouco letrado.

Duas mulheres na fila de banco.

Uma lê, escreve e veste-se bem.

A outra não lê; não escreve, veste.

A primeira, aquela que lê, escreve e veste-se bem, fala pela

Segunda que não lê, não escreve, apenas veste.

A segunda, aquela que não lê, não escreve, veste o que a

Primeira diz; concorda, faz gestos ritmados com a cabeça.

A primeira, a que lê e escreve, marca, aceleradamente, sua

Passagem á caneta, enquanto a segunda, sem pressa, vai

Deixando polegadas como impressão. ${ }^{25}$

A partir dos anos de 1970, a compreensão do universo letrado passou a ser vista como um processo de letramento. O letramento proficiente é a capacidade de o sujeito se colocar em relação um discurso (texto) com outros discursos anteriores a ele, emaranhados nele e posteriores a ele, como possibilidades infinitas de réplica, gerando novos discursos/textos. O discurso/texto é visto como conjunto de sentidos e apreciações de valor das pessoas, situações e objetos do mundo real, dependentes do lugar social do autor e do leitor e da situação de interação entre. Não seria demasiado pensar que o sujeito "vale menos" quanto menos letrado na economia da sociedade letrada.

\footnotetext{
${ }^{24}$ SANTOS. De flores artificiais, p. 50.

${ }^{25}$ SANTOS. De flores artificiais, p. 35.
} 
Por isso, a leitura e a escrita são elementos emancipadores do sujeito. Se se fala pelo outro, instala-se uma relação para além das boas intenções. A palavra de outrem se apresenta não mais na qualidade de informações, indicações, regras, modelos, etc. Ela procura definir as próprias bases de nossa atitude ideológica em relação ao mundo e de nosso comportamento. Como avalia Bakthin, ela surge aqui como a "palavra autoritária e como a palavra internamente persuasiva”, 26

Sem a possibilidade de nos salvaguardar, Jussara Santos escreve sua literatura, de maneira a deixar latente a violência que nos assola.

\begin{abstract}
The objective of this work is to map the several violence scenes contained in De flores artificiais (2002), a book written by Jussara Santos, and to demonstrate the main procedures employed by the author to denounce, through the literary text, the incidence of violent actions of several orders on children and on young women and non-white people.
\end{abstract}

\title{
KEYWORDS
}

Violence; Jussara Santos; infanto-juvenile literature

\section{REFERÊNCIAS}

BAKHTIN, Mikhail. O discurso no romance. In: . Questões de literatura e de estética a teoria do romance. Trad. Aurora Fornoni Bernardini. São Paulo: Hucitec/EdUNESP, 1988. p. $71-210$.

CRUZ, Adélcio de Souza. Narrativas contemporâneas da violência: Fernando Bonassi, Paulo Lins e Ferréz. Belo Horizonte: FALE/UFMG, 2009.

DALCASTAGNÈ, Regina. Estudos de literatura brasileira contemporânea: a personagem do romance. n. 26. Brasília: Editora Universidade de Brasília, jul./dez. 2005.

EVARISTO, Conceição. Da grafia-desenho de minha mãe, um dos lugares de nascimento de minha escrita. In ALEXANDRE, Marcos Antônio (Org.). Representações performáticas brasileiras: teorias, práticas e suas interfaces. Belo Horizonte: Mazza, 2007. p. 16-21.

FIGUEIREDO, Fernanda Rodrigues de. Representação de minorias: a "reversão" do centro. Disponível em: <http: //www.letras.ufmg.br/literafro>. Acesso em: 3 jan. 2011.

\footnotetext{
${ }^{26}$ BAKTHIM. O discurso no romance, p. 142.
} 
HALL, Stuart. Da diáspora: identidades e mediações culturais. Trad. Adelaine La Guardia Resende et al.Belo Horizonte: Editora UFMG, 2003.

HUNT, Peter. A infância sem clichês. Revista Língua Portuguesa, n. 62, p. 11-13, dez. 2010. MICHAUD, Yves. A violência. Trad. L. Garcia. São Paulo: Ática, 1989.

SANTOS, Jussara. De flores artificiais. Belo Horizonte: Sobá, 2002.

SODRÉ, Muniz. Samba, o dono do corpo. Rio de Janeiro: Mauad, 1998.

WALTY, Ivete. Tecnologia, tradição e poesia: a busca da palavra. In: SANTOS, Jussara. De flores artificiais. Belo Horizonte: Sobá, 2002. p. 3-4. 